\title{
CONSTRAINTS FACED BY THE DAIRY FARMERS IN ADOPTING GOOD FARMING PRACTICES IN UTTAR PRADESH
}

\author{
AWADHESH KUMAR SINGH ${ }^{1}$, JANCY GUPTA $^{2}$, MINU SINGH ${ }^{3} \&$ DIKSHA PATEL $^{4}$ \\ ${ }^{1}$ Research Scholar, Department of Extension Education, IAS, BHU, Varanasi, Uttar Pradesh, India \\ ${ }^{2}$ Principal Scientist, Dairy Extension Division, ICAR-NDRI, Karnal, India \\ ${ }^{3,4}$ Research Scholar, Dairy Extension Division, ICAR-NDRI, Karnal, India \\ ABSTRACT \\ A study was conducted, to find out the constraints faced by the dairy farmers in adopting Good Dairy Farming \\ Practices in Uttar Pradesh. The study was restricted to 160 respondents from two districts, namely, Rae Bareli and \\ Varanas, $i$ which were selected randomly. From the study, it was observed that, the most important constraint faced by \\ the farmers in adoption of good animal health practices was "Non-availability of timely treatment facilities". In case of \\ adoption of good hygienic milking practices, most important constraint was "Lack of knowledge about hygienic milk \\ production". "Lack of knowledge about recommended feeding practices of dairy animals" was an important constraint in \\ adoption of good feeding practices. "Lack of scientific housing and milking facilities was the most important constraint \\ found in adoption of good animal welfare practices. Most important constraint in adoption of good environment practices \\ as perceived by the Farmers was "Lack of knowledge about waste disposal practices". "Lack of knowledge of keeping \\ data with financial record" was an important constraint, faced by the farmers in relation to socio-economic management \\ practices. The study suggest that, awareness programs and training may be organized, for capacity building of the \\ farmers in the study area, for adoption of good dairy farming practices. \\ KEYWORDS: Constraints, Good Dairy Farming Practices, Scientific Housing \& Adoption
}

Received: Jul 11, 2017; Accepted: Jun 21, 2017; Published: Jul 07, 2017; Paper Id.: IJASRAUG201717

\section{INTRODUCTION}

Uttar Pradesh, is the largest contributor to the national milk production, contributing around $18 \%$ of total milk production in the country. It has got the second highest cattle population and highest buffalo population in the country. Majority of the rural population of the state, is engaged either in the livestock breeding or dairying in one way or the other. In this state, dairying is an important source of subsidiary income to the farmers. There is need to increase the production of market safe quality milk and milk product, to meet the demand of growing population. Even though Uttar Pradesh stands first in milk production, majority of the farmers are practicing unhygienic and unhealthy milk production practices, thus the produced milk is of poor standards. Good Dairy Farming Practices (GDFP) are used world-wide, which support the farmers to produce and market, safe quality milk to satisfy the quality standards. Good Dairy Farming Practices (GDFP), is an important practical tool used world-wide in supporting farmers, to produce and market, safe quality milk and milk products, to satisfy the expectations of the food industry and consumers (FAO, 2011). The aim of GDFP, is to ensure production of good quality milk at the farm level, by healthy animals and in equilibrium with the environment. The Good Practices tool box consists of, six areas that need to be managed, namely: animal health, hygienic milking, feeding, animal welfare, environment and socio-economic conditions, for production 
of quality milk and milk products, which fulfills the highest expectations of the food industry along with consumers. It is recommended that GDFP should be followed by the farmers. But in Uttar Pradesh, there is limited report on the adoption of GDFP among the farmers. The statistics shows that, wide scale network of milk procurement and marketing exist in Uttar Pradesh. Although, UP is playing leading role in the milk production in the country, the milk yield per animal is low. The main reasons behind this, are the lack of use of scientific practices in milking, inadequate availability of fodder in all season, unavailability of veterinary health services, technological bottleneck etc. Keeping this in mind, the constraints faced by the dairy farmers, in adoption of GDFP was studied purposively in Uttar Pradesh. Hence, this study was undertaken with following objective:

- To identify the constraints in the adoption of good dairy farming practices among the respondents.

\section{MATERIALS AND METHODS}

The present study was undertaken in Uttar Pradesh state, since it ranks first in milk production, and also is rich in bovine population. The study was purposively conducted in, central plain zone (CPZ) and eastern plain zone (EPZ) of Uttar Pradesh. From each zone one district namely, Rae Bareli from central plain zone and Varanasi from eastern plain zone were selected, and from each district, two blocks were randomly selected. From each block, two villages were selected randomly, and from each village 20 respondents were selected, making a total of 160 respondents. Respondents having at least one lactating animal, were selected for data collection. The farmers were personally interviewed with the help of semi-structured interview schedule, to enlist the constraints faced by them in each type of the activities, viz. animal health, hygienic milking, feeding, animal welfare, environment and socio-economic management, and ranked them in terms of importance/ severity. Constraints for the present study, was operationalized as obstacles or hurdles experienced by the dairy farmers in adoption of good dairy farming practices. The respondents were asked to rank, all the constraint relevant to them, according to the degree of importance as perceived by them. The ranks given to constraints, were analyzed by Garret ranking method (Garret, 1981).

Using formula:

Per cent position $=100(\mathbf{R}-\mathbf{0 . 5}) / \mathrm{N}$.

Where, $\mathrm{R}$ is the rank of the individual item in the series and $\mathrm{N}$ is the number of individual items ranked.

\section{RESULTS AND DISCUSSIONS}

Constraints faced by the respondents related to individual Dairy enterprises, were assessed with the locale of the study area i.e. Uttar Pradesh. It was found that, many of these constraints were very serious, and exert variable limitations on the operational efficiency and more importantly, on the productivity of dairy animals.

\section{Constraints in Adoption of Good Animal Health Practices as Perceived by the Farmers}

'Non-availability of timely treatment facilities', was top most constraint faced by the farmers (Table 1). The reason may be that, the veterinary hospitals were far away from the villages, transport facilities were not adequate and also the veterinary doctor were not available when needed. Lack of knowledge of, common contagious diseases, their prevention and control measures, were perceived as second constraint by the farmers, which prevent them from adopting good dairy animal health practices. The reason behind it may be, because they were less educated and also lacked resources for following control measures. These findings were in accordance with that of, Kumar et al. (2012). 'Inadequate 
supply of vaccines' was perceived as third major constraint, faced by farmers. Similar finding were reported by Sarker and Ghosh (2010), in west Bengal where, infrequent visit of veterinary staff was ranked as second and unavailability of vaccines was ranked as tenth constraint respectively. 'Lack of knowledge about vaccination schedule', was perceived as fourth major constraint faced by farmers. The other constraints such as, unawareness about milk borne zoonotic diseases and non-availability of medicines in hospitals, were as ranked fifth and sixth constraint faced by farmers. Varaprasad et al. (2013) found that, non-availability of medicine and vaccines in time was encountered by majority of the farmers, in Chittoor District of Andhra Pradesh.

\section{Constraints in Adoption of Good Hygienic Milking Practices as Perceived by the Farmers}

The results in Table 2 depicts, the ranks given to the constraints faced by the farmers, related to good hygienic milking practices. The most important constraint faced by the farmers was, 'The lack of knowledge about hygienic milk production', for that reason, they did not know about the basic rules of producing hygienic milk and more importantly, the benefits obtained by producing hygienic milk. Second constraint was 'Ignorance about cleaning of milking area', as farmers lack resources, which were used in cleaning the area and secondly, farmers were avoiding to work hard and spend time for dairying, as this is the secondary occupation for most of them. 'Lack of knowledge about cleaning of animal's, was ranked third by most of the farmers, as they were unaware about clean milk production practices. 'Unavailability of appropriate utensils' required for quality milk production and 'Inadequate knowledge about proper cleaning of utensils', were the other major constraints. Singh et al. (2012), also observed that, lack of knowledge about clean milk production was one of the major constraint in Manipur, and similar result was reported from Rajasthan, by Tailor et al. (2012). In a similar study, Surkar et al. (2014) found that, lack of awareness about quality milk production, unavailability of medicine and equipment required for quality milk production, and lack of finance to invest in dairy business, for quality milk production were some of the important constraints perceived by dairy farmers, in adoption of practices related to quality milk production.

\section{Constraints, in Adoption of Good Feeding Practices as Perceived by the Farmers}

Table 3 indicates, the adequate knowledge about provision of clean drinking water to animals, was perceived as the most important constraint in the study area because, most of the farmers did not provide clean drinking water in their home, instead they send their animals in the nearby ponds and canals, for drinking purposes. The second major constraint perceived by farmers was, 'lack of knowledge about recommended feeding practices for dairy animals', for the reason that, they did not follow a particular ratio in feeding their animal and were lacking knowledge about, what, how and when to feed, and the other constraints were 'Lack of knowledge of quality of local feed stuff, 'High cost of compound feed', 'Inadequate land for fodder cultivation' and 'Lack of grazing field'. Singh et al. (2012) and Dhindsa et al. (2014), also observed similar constraints in dairy farming in Punjab, they reported high cost of feed and fodder, inadequate knowledge about balanced feeding, low availability of quality green fodder and dry fodder, as some of the important constraints. Varaprasad et al. (2013), Trailor et al. (2012) and Kumar et al. (2014) reported that, non availability of pasture, high cost of cakes/ concentrate and inadequate area for fodder cultivation, due to small size of operational holding as major constraints perceived by the farmers in their study area (which is in accordance with the findings received). Trailor $e t$ al. (2012) found that, beside high cost of green fodder, dry fodder and concentrates, non availability of green fodder throughout the year and lack of sufficient pasture land for grazing, were the major constraints faced by the dairy farmers. Sarker, Ghosh (2010) and Trailor et al. (2012) found that, lack of knowledge about recommended feeding practices of 
dairy animals, was the top most constraint encountered by the farmers in their respective study area. Nagrale et al (2015) found that, lack of availability of green fodder, low availability and high cost of concentrates, low availability of dry fodder and non availability of land for fodder production were ranked first, second, third and forth constraints respectively, by dairy farmers.

\section{Constraints in Adoption of Good Animal Welfare Practices, as Perceived by the Farmers}

The results in Table 4 depicts that, lack of scientific housing and milking facilities was ranked as first major constraint faced by the farmers, since most of the farmers did not construct cattle shed, as per guideline of good dairy farming practices. Most of the farmers used paddy straw, in the construction of roof of cattle sheds. Similar observation were reported by Singh et al. (2012), Surkar (2014), Sarker and Ghosh (2010) in their respective studies. 'Lack of knowledge, about general principles for ensuring adequacy of food and water, was perceived as second most important constraint faced by the farmers because, most of the farmers were not following a timely routine in providing feed and water to animals. 'Lack of management skills for monitoring animal health and welfare' was perceived as third important constraint by farmers. The farmers, treat these animals with indigenous method, in early stage of disease condition and if the condition of the animal worsens, only then they take the animals the doctor's examination, which is not recommended under good animal welfare practices. This finding was in line with finding of Singh et al. (2012). The fourth important constraint was, lack of awareness about safe handling of animals, to minimize risk of injury, pain and distress. The farmers were unaware about the scientific ways of handling animals, during casting castration, dehorning. etc. 'Lack of ability to identify animal's needs and taking appropriate actions' was perceived as the fifth important constraint, faced by the farmers.

\section{Constraints in Adoption of Good Environment Practices, as Perceived by the Farmers}

The results in Table 5 shows that, 'Lack of knowledge about waste disposal practices' was cited as a major constraint in adopting, good environment practices in the study area. This was because, farmers were not aware of the practices to dispose animal's waste material. They deposit animal waste around the cattle shed, which caused unhygienic

environment. Second important constraint perceived by the farmers was, 'Irregular disposal of dung and animal waste', as the farmers did not dispose the waste material everyday. Unavailability of facilities, for recycling of animal waste was ranked third for the reason that, they did not have proper facilities to use animal waste efficiently and also, they lack knowledge about disposal of animal waste, to use as a fuel and compost, 'Nil awareness on the toxic effects of routinr use of chemicals in agro-livestock industries', was ranked as fourth constraint in the study of locale.

\section{Constraints in Adoption of Good Socio-Economic Management Practices, as Perceived by the Farmers}

Results in Table 6 shows that, 'Lack of knowledge of keeping data versus financial record', was cited as a major constraint in the study area because, they lacked knowledge on maintaining financial records. Similar finding was reported by, Lokhande et al. (2012). Second constraint faced by the farmers was, 'Lack of resources, for providing scientific housing'. Since, most of the farmers were poor in their financial status, so they could not afford to build houses scientifically, to keep their animals. The finding was, in line with that of, Singh et al. (2012) and Surkar et al. (2014). 'Poor availability and access to profitable market', was ranked as third major constraint faced by the farmers, for the reason that, majority of the farmers sold their milk, in PARAG cooperative society. 'Non remunerative price of milk' by the farmers, was ranked four, since they sold milk in local market and milk cooperative, which also did not offer good price. In the 
same way, they lack option for milk sale, whereas production was comparatively high. Similar finding was reported by, Mohapatra et al. (2012) that, non remunerative price for milk was the most important constraint, followed by poor marketing. 'Lack of capital' was ranked fifth because, majority of the farmers followed, subsistence type of farming in which, most of the product was consumed by the farmers themselves, so no capital was gained. 'Unavailability of labour' was ranked sixth, for the reason that, most of labourers were migrating towards the urban area and a part of them, who were left in villages were, involved in MGNAREGA and other employment generation programs, launched by the government. Disinterest in maintaining simple record, was ranked as the most important constraint whereas, shortage of labour was the least important constraint, reported by Lokhande et al. (2012), in their study.

\section{ACKNOWLEDGEMENT}

The authors thankfully acknowledge Director and Advisor, National Dairy Research Institute, Karnal, for providing facilities and valuable guidance for the research work.

\section{CONCLUSIONS}

Good dairy farming practices plays a significant role, in the production of market safe quality milk and milk product in the rural areas, so, we can say that, it is important to every small and marginal farmer, to increase their farm income, from producing quality milk and milk products. From the study, it can be concluded that, the important constraints faced by the farmers in Uttar Pradesh, in adoption of good dairy farming practices were, non-availability of timely treatment facilities, lack of knowledge of common contagious diseases, their prevention and control measures, lack of knowledge about hygienic milk production, lack of knowledge about recommended feeding practices of dairy animals, lack of scientific housing and milking facilities, lack of knowledge of maintaining records and lack of knowledge about waste disposal practice. Taking these constraints in consideration, the government should take initiatives, to broaden the knowledge base of the farmers, related to good dairy farming practices, along with providing resources and facilities related to, veterinary aids, marketing channels and easy finance options, which can help the farmers to deal with the constraints and thereby, open a path towards adoption of good dairy farming practices.

\section{REFERENCES}

1. Nagrale, B. G., Datta, K. K., \& Chauha, A. K. (2015). An analysis of constraints faced by dairy farmers in Vidarbha region of Maharashtra. Indian Journal of dairy science, 68(4), 390-394.

2. Dhinds. S. S., Nanda.R., \& Kumar. B.(2014). Problems and constraints of dairy farming in Fatehgarh Sahib District of Punjab. Progressive Research, 9(1), 250-252.

3. FAO, (2011). Guide to Good Dairy Farming Practice. Rome, Italy: Food and Agriculture Organization

4. Garrett, H. E. (1981). Statistics in psychology and education. Vakils, Feffer and Simons Pvt. Ltd., Bombay, India.

5. Kumar, N., Bishnoi, P., Bishnoi, D. K., \& Kumar, J. (2014). Constraints analysis in $\quad$ adoption of improved dairy farming practices in Haryana India. Asian Journal of Dairy and food research, 33(2), 136-140.

6. Kumar, S., Kumar, B., Kumar, R., \& Sankhala, G. (2012). Farmer's opinion to reduce the constraints in scientific dairy farming practices-a case study. Indian Journal of Animal Sciences, 82(7), 762-766.

7. Lokhande, J. P., Jha, S. K., \& Vaidya, M. D. (2012). Constraints perceived by the Dairy farmers in adoption of scientific dairy farming Practices. Journal of Dairying Foods \& Home Sciences, 31(1), 42. 
8. Mohapatra, A. S., Behera, R., \& Sahu, U. N. (2012). Constraint faced by tribal entrepreneurs in dairy farming enterprise. International Journal of Physical and Social Sciences, 2(7), 171-184.

9. Sarker, D., \& Ghosh, B. K. (2010). Constraints of milk Production: A study on cooperative and non-cooperative dairy farms in West Bengal. Agricultural Economics Research Review, 23, 303-314.

10. Singh, A. S., Singh, K., \& Chakravarty, R. (2012). Constraints perceived by members of Manipur (India) milk producer's cooperative union in practicing improved dairy farming. Journal of Dairying, Foods \& Home Sciences, 31(4), $279-283$.

11. Surkar, S. H., Sawarkar, S. W., Kolhe, R. P., \& Basunathe, V. K. (2014). Constraints Perceived by dairy farmers in quality Milk production. Agricultural Rural Development, 1, 05-07.

12. Tailor, R., Meena, G. L., Sharma, L., \& Sharma, F. L. (20120. Constraints faced by the tribal farmers in dairy farming in Udaipur district. Rajasthan Journal of Extension Education, 20, 187-189.

13. Varaprasad, R. A., Raghunandan, T., Kumar, M. K., \& Gnana, M. P. (2013). Studies on the socio-economic profile and constraints faced by the farmers rearing Jersey x Sahiwal cows in Chittoor district of Andhra Pradesh. International Journal of Science, Environment and Technology, 2(3), 404-409.

\section{APPENDICES}

Table 1: Constraints in Adoption of Good Animal Health Practices as Perceived by the Farmers

\begin{tabular}{|c|l|c|c|}
\hline SI. No. & \multicolumn{1}{|c|}{ Constraints } & Score & Rank \\
\hline 1 & Non-availability of timely treatment facilities & 72 & I \\
\hline 2 & $\begin{array}{l}\text { Lack of knowledge of common contagious diseases, } \\
\text { their prevention and control measures }\end{array}$ & 71 & II \\
\hline 3 & Inadequate supply of vaccines & 63 & III \\
\hline 4 & Lack of knowledge about vaccination schedule & 66 & IV \\
\hline 5 & Unawareness about milk born zoonotic diseases & 59 & V \\
\hline 6 & Non availability of medicine in veterinary hospitals & 47 & VI \\
\hline
\end{tabular}

Table 2: Constraints in Adoption of Good Hygienic Milking Practices as Perceived by the Farmers

\begin{tabular}{|c|l|c|c|}
\hline Sl. No. & \multicolumn{1}{|c|}{ Constraints } & Score & Rank \\
\hline 1 & Lack of knowledge about hygienic milk production & 72 & I \\
\hline 2 & Ignorance about cleaning of milking area & 70 & II \\
\hline 3 & $\begin{array}{l}\text { Lack of knowledge Ignorance about cleaning of animals } \\
\text { before milking }\end{array}$ & 68 & III \\
\hline 4 & $\begin{array}{l}\text { Unavailability of appropriate utensils required for quality } \\
\text { milk production }\end{array}$ & 65 & IV \\
\hline 5 & Inadequate knowledge about proper cleaning of utensils & 58 & V \\
\hline
\end{tabular}

Table 3: Constraints in Adoption of Good Feeding Practices as Perceived by the Farmers

\begin{tabular}{|c|l|c|c|}
\hline Sl. No. & \multicolumn{1}{|c|}{ Constraints } & Score & Rank \\
\hline 1 & $\begin{array}{l}\text { Lack of knowledge about recommended feeding practices of } \\
\text { dairy animal }\end{array}$ & 72 & I \\
\hline 2 & Shortage of green fodder particularly during summer months & 66 & II \\
\hline 3 & Inadequate land for fodder cultivation & 64 & III \\
\hline 4 & High cost of compound feed & 62 & IV \\
\hline 5 & Lack of grazing field & 59 & V \\
\hline 6 & $\begin{array}{l}\text { Inadequate knowledge about providing clean drinking water } \\
\text { to the animals }\end{array}$ & 57 & VI \\
\hline
\end{tabular}

Table 4: Constraints in Adoption of Good Animal Welfare Practices as Perceived by the Farmers
Sl.
Constraints
\begin{tabular}{|l|l|} 
Score & Rank \\
\hline
\end{tabular} 


\begin{tabular}{|c|l|c|c|}
\hline No. & \multicolumn{1}{|c|}{} & \multicolumn{1}{|c|}{} \\
\hline 1 & Lack of scientific housing and milking facilities & 72 & I \\
\hline 2 & $\begin{array}{l}\text { Lack of knowledge about general principles for ensuring } \\
\text { adequacy of food and water }\end{array}$ & 67 & II \\
\hline \multicolumn{1}{|c|}{ Table 4: Contd., } & \multicolumn{1}{|c|}{ 47 } & III \\
\hline 3 & $\begin{array}{l}\text { Lack of management skills for monitoring animal health and } \\
\text { welfare }\end{array}$ & 39 & IV \\
\hline 4 & $\begin{array}{l}\text { Lack of awareness about safe handling of animals to minimize } \\
\text { risk of injury, pain and distress }\end{array}$ & 30 & V \\
\hline 5 & $\begin{array}{l}\text { Lack of ability to identify animals needs and take appropriate } \\
\text { actions }\end{array}$ & &
\end{tabular}

Table 5: Constraints in Adoption of Good Environment Practices as Perceived by the Farmers

\begin{tabular}{|c|l|c|c|}
\hline Sl. No. & \multicolumn{1}{|c|}{ Constraints } & Score & Rank \\
\hline 1 & Lack of knowledge about waste disposal practices & 67 & I \\
\hline 2 & Irregularly disposal of dung and animal waste & 66 & II \\
\hline 3 & Unavailability of facilities for recycling of animal waste & 65 & III \\
\hline 4 & $\begin{array}{l}\text { Unawareness about toxic effect of chemicals routinely } \\
\text { used in agro-livestock industries }\end{array}$ & 64 & IV \\
\hline
\end{tabular}

Table 6: Constraints in Adoption of Good Socio-Economic Management Practices as Perceived by the Farmers

\begin{tabular}{|c|l|c|c|}
\hline Sl. No. & \multicolumn{1}{|c|}{ Constraints } & Score & Rank \\
\hline 1 & Lack of knowledge of record keeping & 70 & I \\
\hline 2 & Lack of resources for providing scientific housing & 69 & II \\
\hline 3 & Poor availability and access to profitable market & 68 & III \\
\hline 4 & Non remunerative price of milk & 65 & IV \\
\hline 5 & Lack of capital & 63 & V \\
\hline 6 & Unavailability of labour & 62 & VI \\
\hline
\end{tabular}


